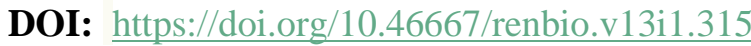

\title{
Ensino e aprendizagem de biomoléculas no ensino médio: extração de DNA e estímulo à experimentação
}

\author{
Teaching and learning of biomolecules in high school: \\ DNA extraction and stimulus to experimentation
}

\author{
Luciana Duarte Martins da Matta ${ }^{1}$, Isabelle Revoredo dos Santos ${ }^{2}$, \\ Stephanny Clarissy da Silva Mendonça ${ }^{3}$, Diego Vinícius Medeiros de Carvalho ${ }^{4}$, \\ Ana Paula Melo da Silveira ${ }^{5}$, Roseane Pereira da Silva ${ }^{6}$
}

\begin{abstract}
Resumo
Este artigo relata a aplicação de aulas experimentais de extração de DNA no Laboratório de Ciências de uma Escola Pública Estadual, a criação e aplicação de um Quiz elaborado na plataforma on line do kahoot sobre DNA com o objetivo de contribuir para a aprendizagem de biomoléculas no ensino de biologia. Foram aplicados questionários, antes (QCP) e após (QVA) as aulas para avaliar conhecimentos prévios e adquiridos, como ainda o kahoot contendo 10 questões sobre DNA. Os dados obtidos com os QCP mostraram que a maioria dos alunos definiram corretamente o DNA, como ainda indicaram sua localização e que apresentam dupla fita. Dados do QVA mostraram que boa parte dos alunos sabe que o DNA é detentor da informação genética.
\end{abstract}

Palavras-chave: Ensino e aprendizagem; biologia; aulas experimentais; kahoot

\begin{abstract}
This article reports application of experimental classes of DNA extraction in the Science Laboratory of a State Public School, creation and application of a Quiz at kahoot's on line platform about DNA to contribute biology teaching. Questionnaires were applied before (QCP) and after (QVA) classes to evaluate previous and acquired knowledge, such as kahoot containing 10 questions about DNA. The data obtained with the QCP showed that most of the students correctly defined the DNA, indicated their location and that have double strands. QVA data showed that most students know that DNA keeps genetic information.
\end{abstract}

Keywords: Teaching and learning; biology; experimental class; kahoot

\footnotetext{
${ }^{1}$ Doutora em Ciências Biológicas - Universidade Federal de Pernambuco - Brasil. Professora associada

- Universidade Federal do Rio Grande do Norte. Natal, RN - Brasil. E-mail: lucianadamatta@ hotmail.com

${ }^{2}$ Graduação em Ciências Biológicas - Universidade Federal do Rio Grande do Norte. Natal, RN - Brasil. Email: isa_rds@hotmail.com

${ }^{3}$ Graduanda em Ecologia - Universidade Federal do Rio Grande do Norte. Natal, RN - Brasil. E-mail: stephannymendonca@hotmail.com

${ }^{4}$ Graduado em Ciências Biológicas - Universidade Federal do Rio Grande do Norte. Natal, RN - Brasil. E-mail: diegovmcarvalho@gmail.com

${ }^{5}$ Graduanda em Ecologia - Universidade Federal do Rio Grande do Norte. Natal, RN - Brasil. E-mail: melo98@outlook.com

${ }^{6}$ Mestra em Ciâncias da Saúde - Universidade Federal do Rio Grande do Norte. Natal, RN - Brasil. Professora de Biologia - da Escola Estadual Desembargador Floriano Cavalcante. Natal, RN - Brasil. E-mail: roseanebiol@hotmail.com
}

Submetido em: 05/05/2020 - Aceito em: 15/06/2020 
DOI: https://doi.org/10.46667/renbio.v13i1.315

\section{Introdução}

É perceptível a constante preocupação dos professores das áreas de ciências e biologia em procurar melhorar o ensino e aprendizagem em tais áreas, buscando maior participação e interesse dos alunos (ANDRADE; VASCONCELOS, 2014). Diante dos temas complexos que envolvem as Ciências da Natureza, é preciso maior contextualização com o cotidiano a fim de instigar os alunos a criar relações, explicar processos, construir modelos, como ainda despertar o raciocínio científico. Discute-se a longa data a necessidade de um ensino de biologia mais dinâmico e atrativo desenvolvendo-se, por exemplo, aulas práticas ou a realização de atividades investigativas (CARMO; SCHIMIN, 2008).

Novas metodologias de ensino vêm sendo desenvolvidas nos últimos anos e ganhando espaço no ambiente escolar, dentre elas a utilização de tecnologias educacionais podem ser importantes ferramentas neste processo, pois possibilita maior aproximação à realidade atual dos alunos (CHIOFI; OLIVEIRA, 2014; MATTA, et al., 2018).

As bases nacionais curriculares (BNCC) indicam para a área de Ciências da Natureza:

Portanto, ao longo do Ensino Fundamental, a área de Ciências da Natureza tem um compromisso com o desenvolvimento do letramento científico, que envolve a capacidade de conhecer e interpretar o mundo (natural, social e tecnológico), mas também de transformá-lo com bases nos aportes teóricos e processuais das ciências (BNCC, 2017, p.321).

Percebe-se assim a importância de estimular a implementação de metodologias que favoreçam o processo de ensino e aprendizagem de Ciências da Natureza já no ensino fundamental, quando a partir dos conhecimentos básicos adquiridos, os estudantes poderão conhecer, interpretar e opinar sobre temas importantes relacionados ao seu cotidiano, nas áreas das ciências e tecnologias (NASCIMENTO, 2016).

Quando se considera a aprendizagem no campo das Ciências da Natureza no ensino médio, a BNCC aponta a importância dos processos e práticas de investigação, como na proposição de resolução de problemas, teste hipóteses, elaboração de argumentos e explicações, planejamento e realização de atividades experimentais e de campo, ou seja, o aluno necessita ser desafiado. Os diálogos e os pensamentos críticos deverão ser priorizados (BNCC, 2017).

Para acompanhar as rápidas mudanças tecnológicas e das ciências faz-se necessário que os docentes revejam suas práticas pedagógicas frequentemente, tarefa nada fácil, já que tais atitudes requerem políticas de apoio, investimentos e incentivos, seja da escola ou dos órgãos governamentais, que estimulará a formação continuada dos docentes, adequação de espaços para receber as novas metodologias, disponibilização de recursos didáticos e laboratoriais, além de acesso a uma boa rede de internet. 
Nesta perspectiva, muitos docentes já vêm desenvolvendo metodologias mais ativas no intuito de mudar um pouco a realidade do ensino de Ciências e biologia, seja utilizando ferramentas tecnológicas (MATTA, et al., 2018), através da educação dialógicoproblematizadora ou ensino-investigativo (ABEGG; BASTOS, 2005) e experimentação (SILVA et al., 2017; CARVALHO et al., 2018; NASCIMENTO, 2016; MENDONÇA, et al., 2018).

Através do projeto de extensão intitulado: "Novas Perspectivas de Interação entre Escola e Universidade: Contribuições para o Ensino de Biologia", o grupo envolvido neste teve a oportunidade de realizar intervenções em uma escola pública de Natal. Assim, o objetivo deste trabalho foi desenvolver aulas experimentais de extração de DNA, como também, elaborar e aplicar um Quiz criado pelos estudantes ligados ao projeto na plataforma on line do kahoot com intenção de colaborar na compreensão e estudo da molécula de DNA, auxiliando assim o ensino e aprendizagem de biomoléculas nesta escola, como ainda o estímulo à realização de experimentações e o desenvolvimento do pensamento científico.

\section{Metodologia}

As aulas práticas de extração de DNA foram realizadas no ano de 2018 no Laboratório de Ciências da Escola Estadual Desembargador Floriano Cavalcante, contemplando 71, 32 e 51 alunos regularmente matriculados nas turmas do $1^{\circ}, 2^{\circ}$ e $3^{\circ}$ anos do ensino médio, respectivamente. Dias após a realização das aulas práticas, aplicou-se um Kahoot com as turmas a respeito do assunto em suas respectivas salas de aula. Tais atividades foram empregadas durante o desenvolvimento do projeto de extensão intitulado "Novas perspectivas de interação entre escola e universidade: contribuições para o ensino de biologia". Nestas participaram os alunos bolsistas e voluntários do projeto, além da professora da UFRN responsável por este e da professora de biologia das turmas da escola.

As atividades práticas foram realizadas em cinco etapas:

Etapa 01 - Questionário de levantamento dos conhecimentos prévios (QCP)

Buscando fazer um levantamento dos conhecimentos dos alunos acerca da molécula de DNA, um questionário contendo três perguntas foi aplicado. As duas primeiras questões foram objetivas e a terceira discursiva.

A primeira questão: Qual a melhor definição para Ácido Desoxirribonucleico (DNA)? As alternativas apresentadas para escolha foram: (a) Composto orgânico responsável por catalisar as reações químicas; (b) Maior unidade fundamental da vida com função estrutural e funcional aos seres vivos; (c) Molécula presente em seres vivos que carrega toda informação genética do organismo; (d) Substância química sintetizada pelo sistema endócrino que atua como sinalizador celular. 
DOI: https://doi.org/10.46667/renbio.v13i1.315

A segunda questão: Complete as lacunas na frase: “A informação genética, importante para os processos de transmissão das características biológicas entre os organismos, encontrase organizada, predominantemente, sob a forma de que se localizam no interior do (a) ". As palavras que preenchem corretamente as lacunas são: (a) Cromossomos e complexo de Golgi; (b) Cromossomos e núcleo; (c) Cromatinas e mitocôndria; (d) Cromatinas e núcleo.

A terceira questão: Que moléculas compõem a estrutura do DNA? Tente desenhar (no espaço abaixo) a molécula de DNA contendo seus constituintes.

\section{Etapa 02 - Diálogo-discussão do tema e explicação sobre a atividade}

Após a aplicação do QCP, um diálogo foi estabelecido com os alunos buscando debater sobre o tema DNA e genética. Buscou-se discutir conceitos acerca do tema, a estrutura do DNA e sua importância. Além disso, orientações sobre a prática foram feitas, quando informou-se que o DNA seria extraído do tomate, foi discutida a importância da solução de lise, composta por $\mathrm{NaCl}$, detergente e água destilada, a qual seria utilizada por eles para extrair as moléculas de DNA do interior das células e ainda sobre a importância de se utilizar o álcool etílico PA gelado ao final da prática, para assim obter o DNA, o qual seria visualizado na parte superior da solução.

\section{Etapa 03 - Extração do DNA}

Feito isso, os estudantes foram divididos em grupos, receberam os roteiros da aula prática e deram início aos procedimentos solicitados. Inicialmente, eles foram estimulados a preparar a solução de lise conforme estava explicitado no roteiro. Eles pesaram o $\mathrm{NaCl}$ em uma balança e o depositaram em uma proveta, em seguida pipetaram a quantidade desejada do detergente e reuniram ao sal adicionando água até o volume indicado, produzindo a solução. Posteriormente, cortaram meio tomate em pedaços menores visando aumentar a superfície de contato com a solução de lise, a qual foi adicionada posteriormente sobre estes no almofariz. Com o auxílio de um pistilo, os tomates foram macerados para facilitar a ação da solução, que intensificou a quebra de parede celular e membranas para extravasar o constituinte desejado. Em seguida, com o auxílio de gaze, funil e béquer, o material solúvel foi filtrado para um béquer, enquanto o restante, contendo o material não solubilizado, foi descartado. $\mathrm{Na}$ sequência, os alunos pipetaram $5 \mathrm{~mL}$ da solução obtida para um tubo de ensaio, quando a esta foi adicionado $5 \mathrm{~mL}$ de álcool PA gelado, com cuidado e lentamente pelas paredes do tubo. Feito isso, foi possível perceber a perda de solubilidade dos DNAs, quando estes se deslocaram para a solução superior, sendo possível observá-los.

\section{Etapa 04 - Questionário de verificação da aprendizagem (QVA)}

Ao final da aula prática, discussões sobre o experimento e os resultados obtidos foram realizadas. Feito isso, um novo questionário foi aplicado, com a intenção de verificar as contribuições da aula prática na compreensão da temática estudada.

A primeira questão: Durante a investigação de uma cena de crime, você encontra uma gota de sangue em uma camiseta de um possível criminoso. O sangue é um tecido que circula

REnBio - Revista de Ensino de Biologia da SBEnBio - ISSN: 1982-1867 - vol. 13, n. 1, p. 59-73, 2020 
DOI: $\underline{\text { https://doi.org/10.46667/renbio.v13i1.315 }}$

pelo corpo e é composto por diversas células. Para obter provas de acusação do possível causador do crime, em qual estrutura você deve procurar o material genético? Justifique sua resposta.

A segunda questão: Tendo em vista que apenas a vítima e o agressor estiveram no perímetro do crime, tal prova é confiável para acusar alguém? Justifique sua resposta.

A terceira questão solicitava uma associação entre termos e suas definiç̧ões: Faça a devida associação entre termo e conceito. (a) nucleotídeo $\quad(b)$ gene $\quad(c)$ cromossomo $\quad(d)$ DNA (e) genoma. Estes termos deveriam ser associados às definições: (_) longa sequência de material genético altamente compactada; (_) molécula responsável pelo armazenamento do material genético; (_ ) sistema gênico capaz de identificar uma espécie; (_) molécula que se polimeriza para formar o DNA; (_ segmento do código genético capaz de originar os RNAs e, indiretamente, biomoléculas.

Etapa 05- Desenvolvimento do Kahoot:

Foi criado um Quiz on line utilizando a plataforma do Kahoot: https://create.kahoot.it/share/quiz-genetica-nivel-basico-ensino-medio/7bcd2506-cd55-4e4c-91bed3d567cc3abf. Este continha 10 (dez) questões de múltipla escolha com 4 alternativas sendo 3 incorretas e 1 correta. As questões criadas foram baseadas na aula prática de DNA aplicada às turmas do $1^{\circ}, 2^{\circ}$ e $3^{\circ}$ anos do ensino médio.

As perguntas foram:

01) Qual a melhor definição para material genético? (a) Composto orgânico responsável por catalisar reações químicas; (b) Maior unidade fundamental da vida, com função estrutural; (c) Molécula carreadora de toda informação genética do organismo e (d) Substância química sintetizada pelo sistema endócrino.

02) O material genético dos organismos eucariontes encontra-se organizado no... (a) Citosol; (b) Retículo Endoplasmático; (c) Núcleo; (d) Complexo Golgiense.

03) Nos eucariotos, o DNA enrola-se em histonas, organizando o material genético na forma de... (a) Gene; (b) Centrômero; (c) Núcleo; (d) Cromatina

04) O DNA é constituído por polímeros de... (a) Glicídeos; (b) Aminoácidos; (c) Nucleotídeos; (d) Lipídeos.

05) Os nucleotídeos são formados por três componentes. Dentre tais componentes, excluise: (a) Base Nitrogenada; (b) Pentose; (c) Grupamento Fosfato; (d) Ácido Graxo

06) Sequência completa de DNA de um organismo. Tal conceito refere ao... (a) Nucleotídeo; (b) Gene; (c) Cromossomo; (d) Genoma. 
DOI: https://doi.org/10.46667/renbio.v13i1.315

07) Porção capaz de ser transcrita e originar, indiretamente, biomoléculas. Tal conceito se refere ao... (a) Nucleotídeo; (b) Gene; (c) Cromossomo; (d) Genoma.

08) Para obter provas de um possível criminoso, em qual compartimento celular procurase o DNA? (a) Sangue; (b) Complexo golgiense; (c) Núcleo; (d) Mitocôndria.

09) Durante a aula prática, qual a função da solução de análise? (a) Sintetizar DNA; (b) Impedir a extração de DNA; (c) Formar parede celular e membranas (d) Romper parede celular e membranas.

10) Durante a prática, a extração de DNA foi realizada a partir de um organismo... (a) Eucarioto; (b) Procarioto; (c) Acelular; (d) Unicelular.

\section{Resultados e Discussão}

Durante a aplicação das aulas práticas na escola foi possível perceber a boa recepção dos alunos que, aparentemente, gostaram da mudança do cenário habitual, ou seja, a saída da sala de aula para o laboratório. É perceptível que estes se empolgam com aulas experimentais, pois por diversos momentos, durante a atividade, nos declararam preferir tais aulas às tradicionais, no ambiente da sala de aula. Tais demonstrações de satisfação nos estimula a realização destas de maneira ainda mais constante nas escolas participantes do projeto.

Quando os dados obtidos nos QCP foram analisados, foi possível perceber que, em resposta à primeira questão sobre a definição de DNA, $90 \%, 97 \%$ e $88 \%$ dos alunos do $1^{\circ}, 2^{\circ}$ e $3^{\circ}$ anos, respectivamente, foram capazes de definir corretamente o composto, marcando a aletrnativa $\mathrm{C}$ que afirmava: Molécula presente em seres vivos que carrega toda informação genética do organismo. Tais resultados poderão ser observados na figura 1. 
DOI: https://doi.org/10.46667/renbio.v13i1.315

Figura 1: Porcentagem de alunos matriculados no ensino médio que responderam a questão 01 dos questionários de levantamento dos conhecimentos prévios- QCP

(ver metodologia).

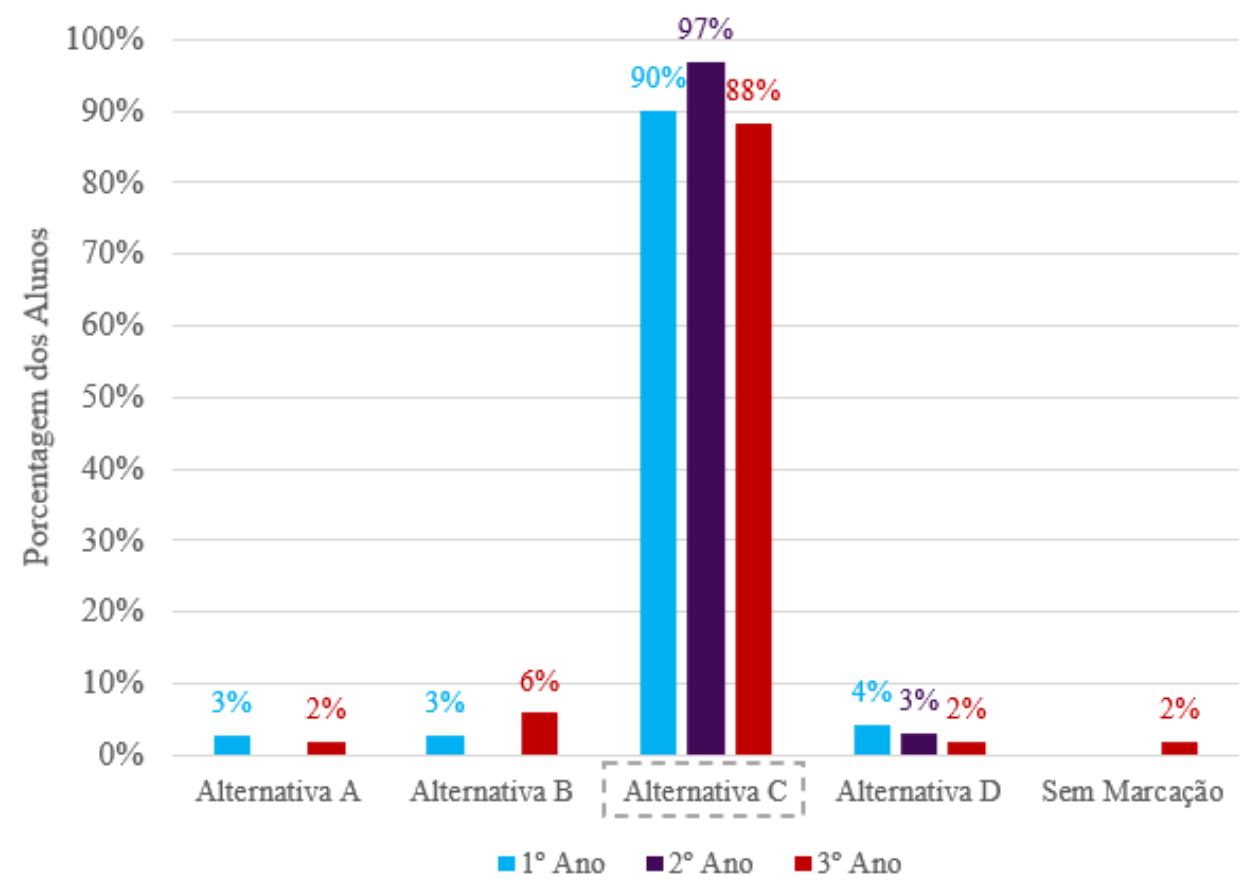

Fonte: Arquivo próprio, 2018.

Na figura 2 são mostrados os resultados obtidos após analisada a questão 02 do QCP. As respostas mostraram que $70 \%, 84 \%$ e $78 \%$ dos alunos matriculados nas turmas do $1^{\circ}, 2^{\circ}$ e $3^{\circ}$ anos, respectivamente, acreditam que a informação genética (o DNA) encontra-se sob a forma de cromossomos e que está localizado no núcleo celular. Porcentagens muito pequenas dos alunos acharam que o material genético encontra-se sob a forma de cromatina, marcando a alternativa D. Assim, nota-se que os alunos não compreendem as diferenças básicas entre cromatinas e cromossomos. Ambos são o DNA em diferentes momentos celulares, a cromatina está presente na intérfase, quando a célula não está em divisão, e apresenta diferentes níveis de compactação. Quando a célula vai se dividir, a cromatina muda a morfologia, composição e função aumentando ainda mais a compactação e se individualizando, formando os cromossomos (SCHER; FEITOSA, 2009). Apesar dos estudantes terem demonstrado pouco conhecimento acerca das diferenças entre as duas estruturas, estas apresentam a mesma identidade biológica, o que não torna isto tão preocupante. 
DOI: https://doi.org/10.46667/renbio.v13i1.315

Figura 2: Porcentagem de alunos matriculados no ensino médio que responderam a questão 02 dos questionários de levantamento dos conhecimentos prévios- QCP (ver metodologia).

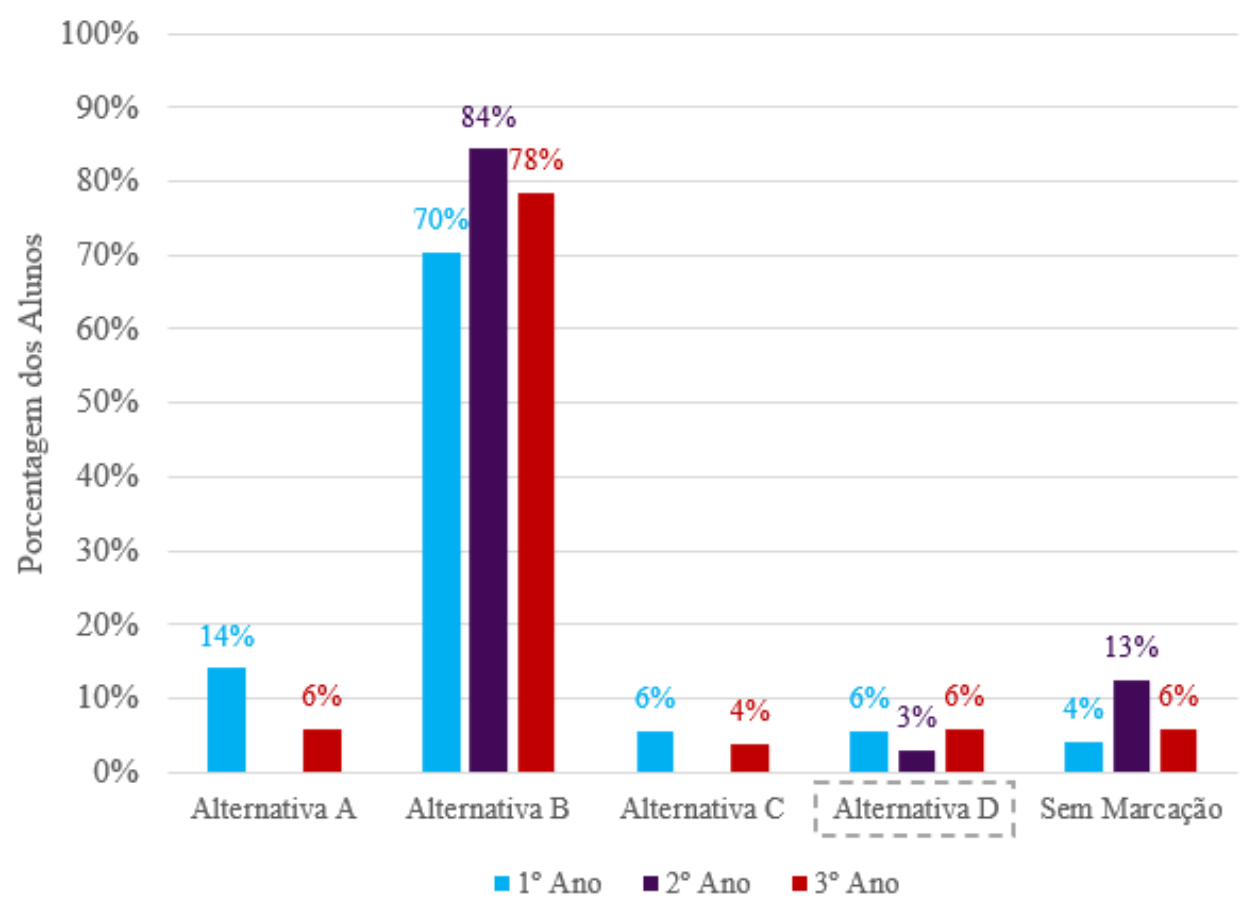

Fonte: Arquivo próprio, 2018.

Ao analisar os imagens produzidas pelos alunos quando solicitado que estes desenhassem a molécula do DNA contendo seus constituintes na terceira questão do QCP, foi possível observar (figura 3) que $37 \%, 69 \%$ e $75 \%$ dos alunos matriculados nas turmas do $1^{\circ}$, $2^{\circ}$ e $3^{\circ}$ anos, respectivamente, desenharam uma dupla fita indicando a ligação entre estas. Fica claro que os alunos do último ano do ensino médio foram capazes de desenhar com maior propriedade a molécula, isto pode ser justificado pelo fato destes alunos já terem um conhecimento maior da própria molécula, como também do conteúdo de genética ministrado no $3^{\circ}$ ano. Desta maneira, os alunos conseguem expressar melhor o conhecimento adquirido. Ressalta-se ainda que, $27 \%$ dos alunos do $3^{\circ}$ ano foram capazes de indicar em suas imagens a presença dos nucleotídeos ou das bases nitrogenadas. Os resultados são satisfatórios, o que comprova que os estudantes têm compreensão da estrutura complexa da molécula de DNA, talvez este interesse também seja influenciado pela mídia devido às várias descobertas envolvendo informação genética, o sequênciamento do genoma humano, investigações criminosas, como ainda os testes de paternidade, etc. 
DOI: https://doi.org/10.46667/renbio.v13i1.315

Figura 3: Porcentagem de alunos matriculados no ensino médio que responderam a questão 03 dos questionários de levantamento dos conhecimentos prévios- QCP (ver metodologia).

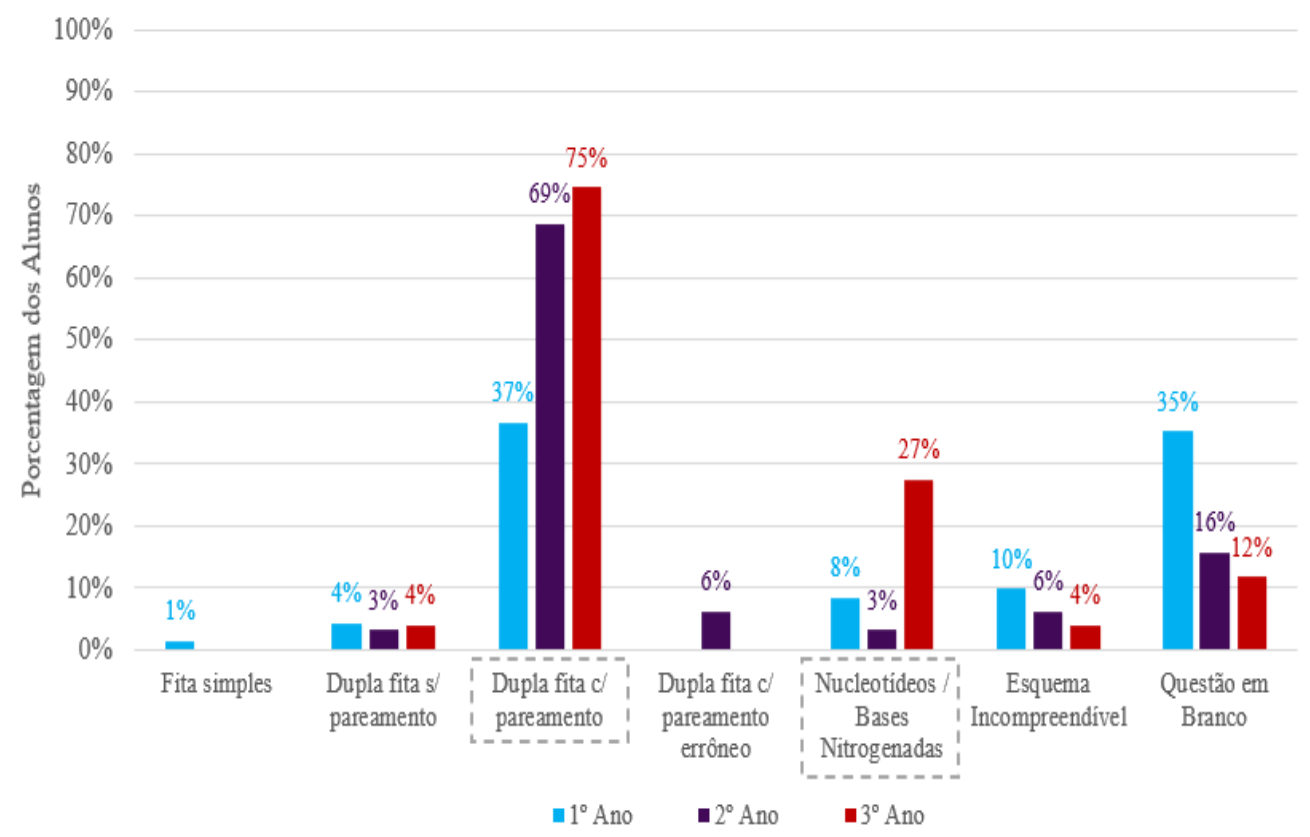

Fonte: Arquivo próprio, 2018.

Após a aplicação do QCP, a aula prática foi aplicada, quando os alunos tiveram a oportunidade de, seguindo um protocolo experimental, extrair e observar a molécula de DNA (figura 4). Durante o desenvolvimento da aula eles tiveram a chance de sanar várias dúvidas, discutindo-se vários aspectos referentes ao tema, como a função da solução de lise, que auxilia no rompimento da parede celular e membranas para que o DNA, presente no núcleo, possa ser extraído. Discutiu-se ainda sobre a estrutura do DNA, sua composição na forma de nucleotídeos e a sua função. Os alunos foram capazes de seguir o protocolo experimental proposto. Todos os dados nos levam a crer que o letramento científico foi estimulado em todo este processo, como ainda o ensino por investigação, exigências da BNCC para o ensino de Ciências da Natureza (BNCC, 2017). 
DOI: https://doi.org/10.46667/renbio.v13i1.315

Figura 4: A fotografia A mostra os materiais utilizados na aula prática dispostos sobre as bancadas do laboratório de ciências da escola antes da atividade. A fotografia B mostra a foto do DNA sendo extraído por um dos grupos de alunos.

A

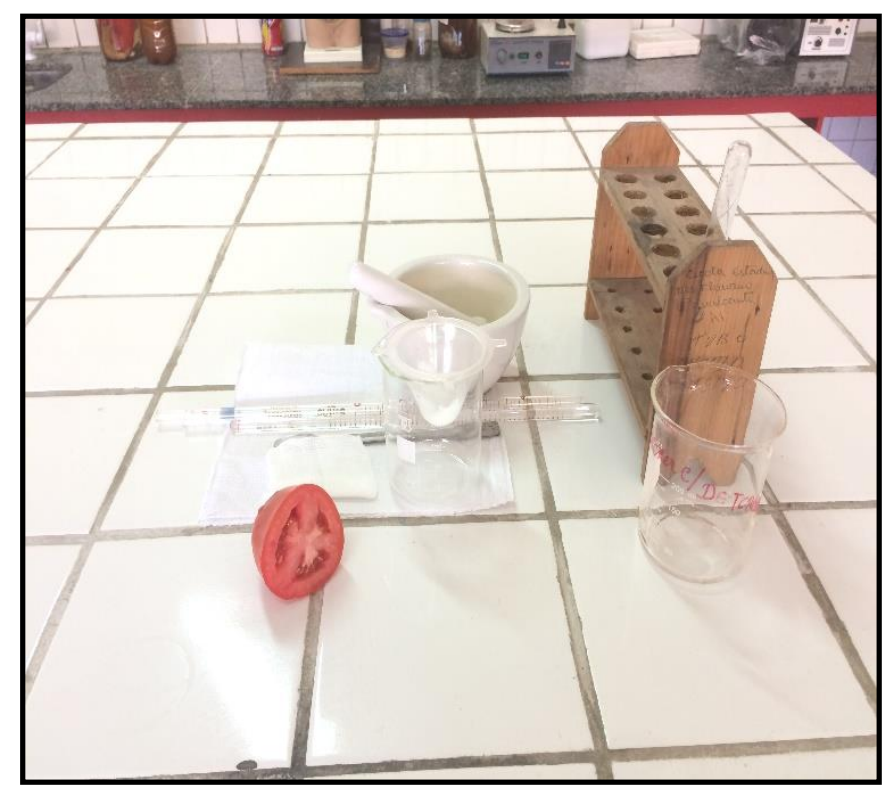

B

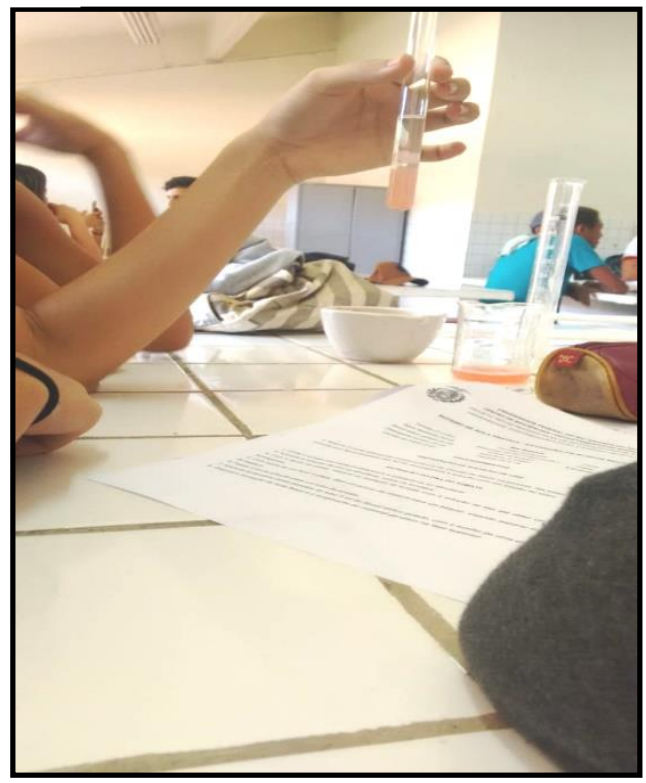

Fonte: Arquivo próprio, 2018.

Após a aula prática, um outro questionário foi aplicado (QVA). A primeira pergunta criava uma atmosfera de investigação, quando se questionava onde poderia ser encontrado o material genético de um possível criminoso que deixou vestígios de sangue na cena de um crime. $49 \%$ dos alunos do $1^{\circ}$ ano apontaram que seria encontrado no DNA (figura 5). $19 \%$ dos alunos do $2^{\circ}$ ano que estariam nos cromossomos. Acredita-se que tais alunos não tenham compreendido a questão, pois apontaram que o material genético seria encontrado no DNA ou no cromossomo. É possível que também tenham feito alguma confusão acerca dos conceitos e não conseguiram relacionar o conhecimento adequadamente, pois o DNA é o próprio material genético. Foi possível verificar que $24 \%, 31 \%$ e $32 \%$ dos alunos do $1^{\circ}, 2^{\circ}$ e $3^{\circ}$ anos, respectivamente, foram capazes de apontar que tal molécula poderia ser encontrada no núcleo das células. Esse era o resultado esperado por nós, já que grande parte dos alunos foi capaz de marcar corretamente a questão 2 do QCP indicando que o material genético estava no núcleo. Imagina-se que os alunos não estão realmente acostumados a lidar com questões que exijam aplicação de conhecimento e não tiveram a habilidade de perceber a simplicidade desta, mas que exigia que estes se expressassem. Isso mostra que os alunos necessitam desenvolver tais habilidades, estas nem sempre o ensino tradicional dá conta, por isto a necessidade de se ter mais aulas dialogadas, fora do ambiente tradicional de sala de aula, resolução de problemas, desafios, para que estes possam ser instigados a pensar, refletir e ressignificar o conhecimento. 
DOI: https://doi.org/10.46667/renbio.v13i1.315

Figura 5: Porcentagem de alunos matriculados no ensino médio que responderam a questão 01 dos questionários de verificação de aprendizagem- QVA (ver metodologia).

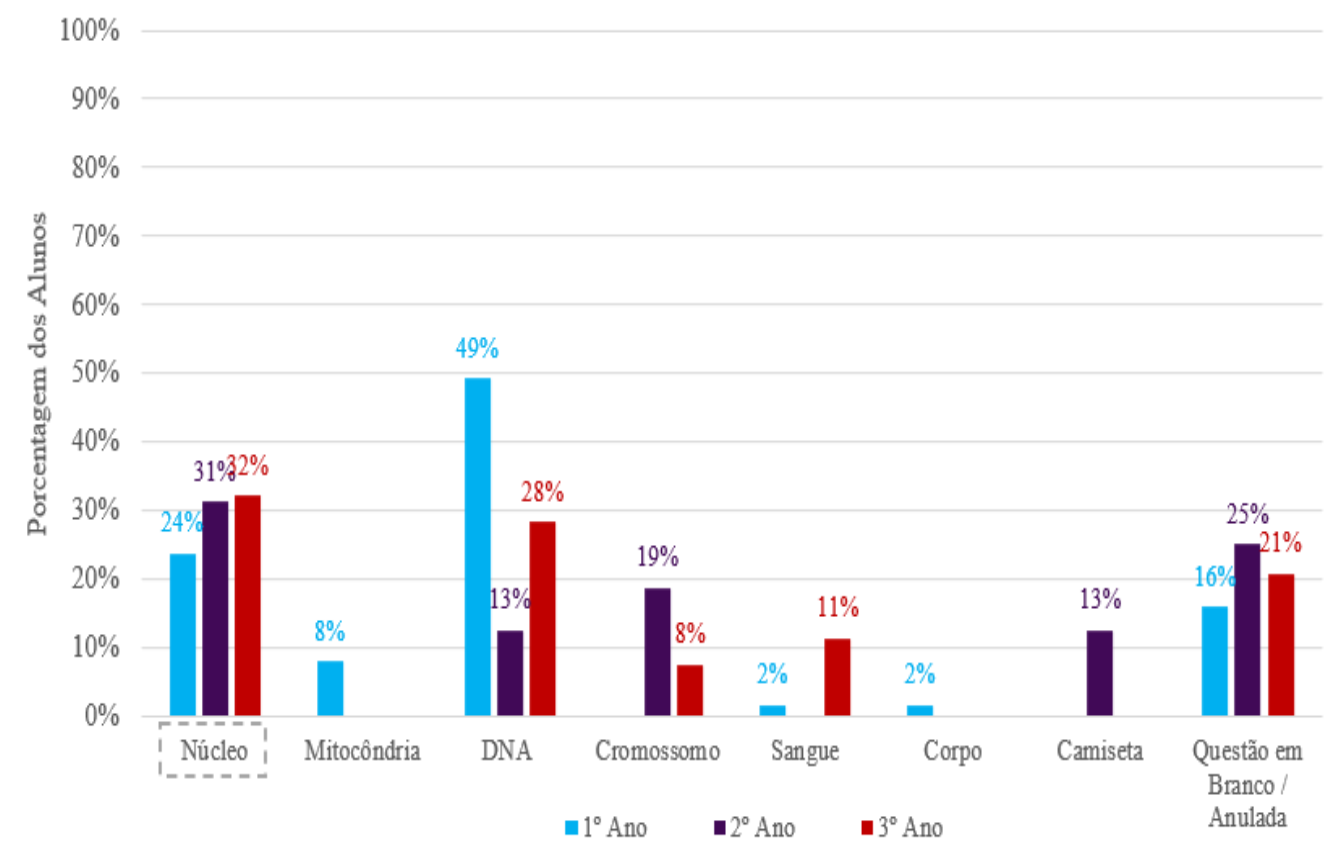

Fonte: Arquivo próprio, 2018.

A questão 02 do QVA perguntava se a prova obtida na região do crime seria suficiente para incriminar alguém, já que somente o agressor e a vítima estavam neste local. Solicitava que justificasse a questão. Conforme mostrado na figura $6,30 \%, 56 \%$ e $47 \%$ dos alunos do $1^{\circ}$, $2^{\circ}$ e $3^{\circ}$ anos, respectivamente, responderam a essa pergunta afirmando que sim e a justificaram corretamente. Isso indica que boa parte destes alunos têm consciência do DNA como detentor da informação genética e próprio de cada organismo, ressalta-se que $44 \%, 19 \%$ e $28 \%$ dos alunos do $1^{\circ}, 2^{\circ}$ e $3^{\circ}$ anos, respectivamente, mostraram que sabiam que sim, mas não souberam, ou não quiseram justificar. 
DOI: https://doi.org/10.46667/renbio.v13i1.315

Figura 6: Porcentagem de alunos matriculados no ensino médio que responderam a questão 02 dos questionários de verificação de aprendizagem- QVA (ver metodologia).

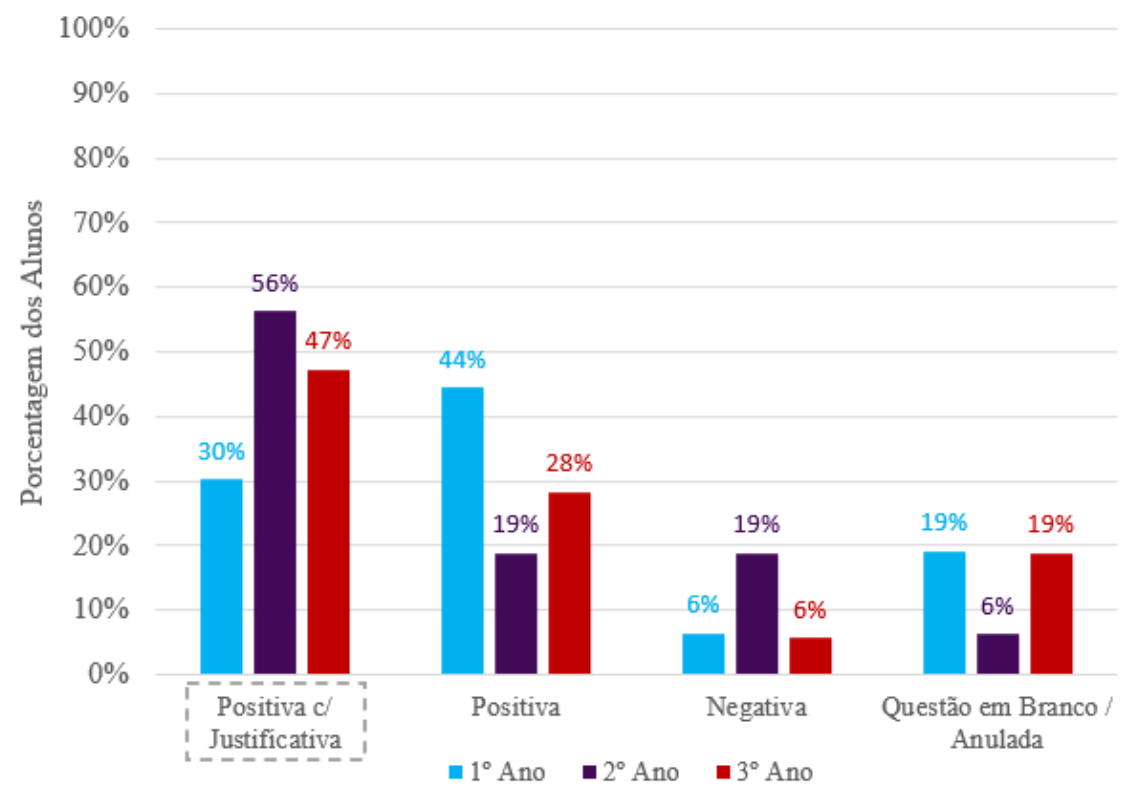

Fonte: Arquivo próprio, 2018.

Na última questão do QVA, solicitávamos que fosse feita uma associação entre algumas estruturas e suas definições (figura 7). Foi identificado que $69 \%$ dos alunos do $2^{\circ}$ ano foram capazes de relacionar corretamente o nome DNA e sua definição, enquanto $30 \%$ e $19 \%$ dos alunos dos $1^{\circ}$ e $3^{\circ}$ anos foram capazes de indicá-los corretamente. $19 \%$ dos alunos do $3^{\circ}$ ano foram capazes de relacionar a palavra cromossomo ao seu significado. $33 \%$ dos alunos do $1^{\circ}$ ano relacionaram corretamente o nome gene ao seu significado e $23 \%$ dos alunos do $3^{\circ}$ ano conseguiram relacionar corretamente a palavra genoma, ao seu significado. Alguns destes resultados são muito bons, pois já demonstra que alguns alunos estão sendo capazes de diferenciar tais estruturas que tem alto grau de complexidade e necessitam maior capacidade de compreensão. Mesmo assim, percebe-se que tais definições e diferenciações devem ser melhor trabalhadas, utilizando metodologias de ensino diferentes, e que favoreçam a aprendizagem significativa para que estes adquiram a capacidade de diferenciá-los adequadamente através de quaisquer instrumento de verificação de aprendizagem. 
DOI: https://doi.org/10.46667/renbio.v13i1.315

Figura 7: Porcentagem de alunos matriculados no ensino médio que responderam a questão 03 dos questionários de verificação de aprendizagem- QVA (ver metodologia).

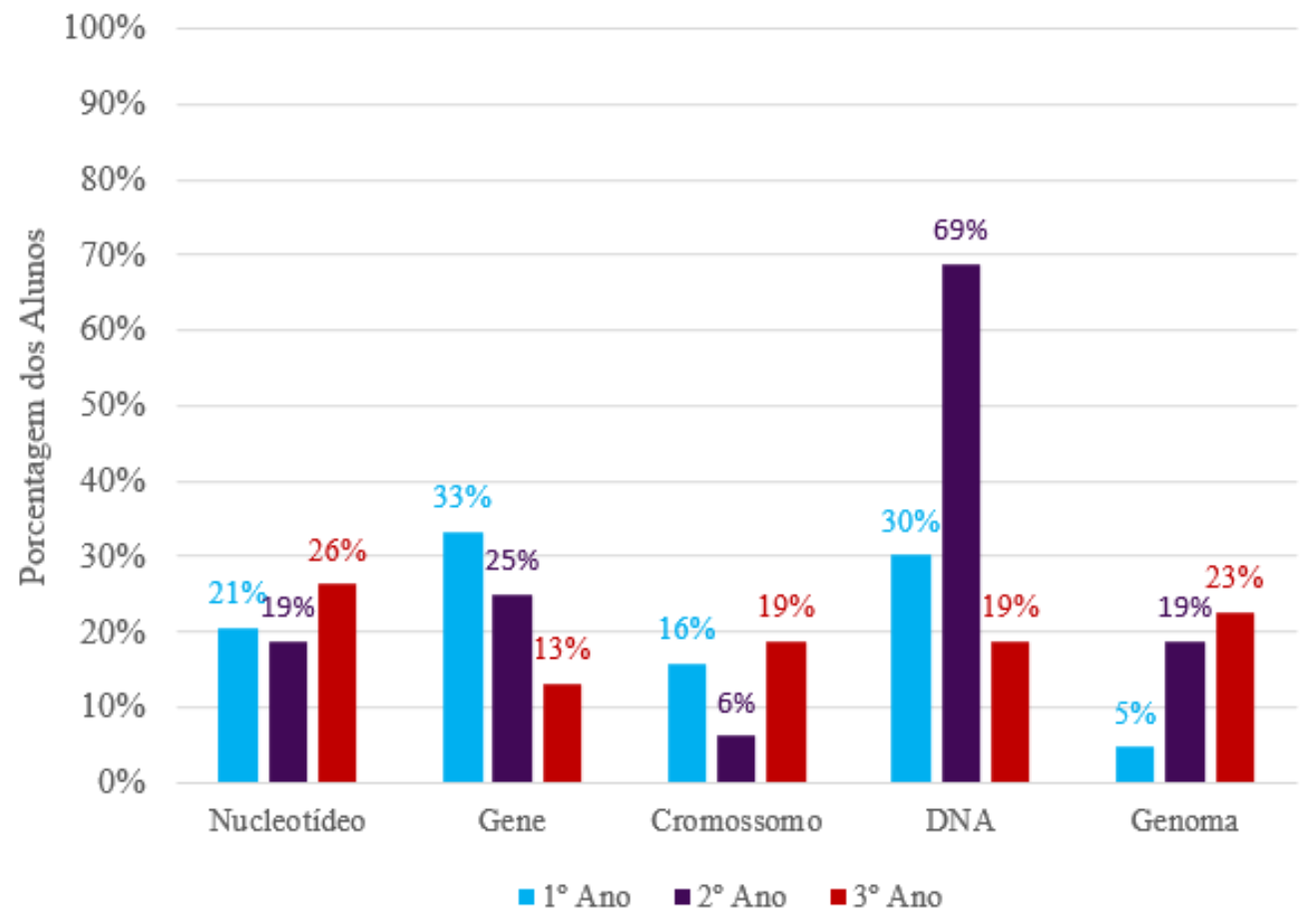

Fonte: Arquivo próprio, 2018.

Dias após as aulas práticas, o grupo do projeto retornou à escola para aplicar um kahoot elaborado para ser desenvolvido com os alunos que participaram da aula prática (ver as questões na metodologia). Os alunos demonstraram ótima aceitação da metodologia do kahoot que, neste caso, serviu como ferramenta auxiliar do processo de ensino e aprendizagem da molécula do DNA. Como a internet da escola estava muito instável, selecionou-se alguns dados mais relevantes para apresentar, aqueles que sofreram menos interferência das quedas do sinal, quando foi possível contabilizar melhor as respostas dos alunos.

Em resposta à primeira questão do kahoot, $78 \%$ dos alunos dos $1^{\circ}, 2^{\circ}$ e $3^{\circ}$ anos foram capazes de marcar a alternativa correta sobre a definição de DNA. E quando perguntado sobre a localização deste, $61 \%, 44 \%$ e $56 \%$ dos alunos dos $1^{\circ}, 2^{\circ}$ e $3^{\circ}$ anos, respectivamente, responderam que seria no núcleo celular. Ao serem questionados sobre o compartimento celular em que se deve procurar o DNA de um possível criminoso $78 \%, 67 \%$ e $33 \%$ dos alunos $\operatorname{dos} 1^{\circ}, 2^{\circ}$ e $3^{\circ}$ anos, respectivamente, responderam que seria no sangue. Tais porcentagens foram menores que aquelas obtidas no QCP, quando eles foram questionados acerca da definição do DNA e sua localização. É importante ressaltar que esta ferramenta tecnológica era novidade para os estudantes no periodo, sendo este o primeiro contato deles com este tipo de quiz on line. Percebeu-se que, em alguns momentos determinados estudantes não responderam as questões dentro do tempo permitido e as perderam, como ainda, a internet da escola por vezes estava instável, o que prejudicou as respostas em algumas questões, isso pode explicar a porcentagem menor de acertos obtidos. Ainda, quando perguntado sobre a constituição do 
DNA, $33 \%, 11 \%$ e $32 \%$ dos alunos dos $1^{\circ}, 2^{\circ}$ e $3^{\circ}$ anos, respectivamente, afirmaram ser de nucleotídeos. Ao serem perguntados sobre o que significava a sequência completa de DNA de um organismo vivo, somente $17 \%, 11 \%$ e $33 \%$ dos alunos dos $1^{\circ}, 2^{\circ}$ e $3^{\circ}$ anos, respectivamente, responderam que seria o genoma. Ressalta-se a necessidade de trabalhar tais temas com metodologias ativas, o que causará, provavelmente, uma aprendizagem mais significativa.

\section{Considerações Finais}

É perceptível que o ensino tradicional, sozinho, não dá conta de desenvolver as habilidades e competências necessárias à educação da atualidade. Os alunos dos dias atuais têm as informações em suas mãos através dos seus smartphones, tablets e computadores. A escola de hoje necessita de investimentos em internet, na formação continuada de seus docentes, em diferentes práticas educativas e em espaços diferentes que propiciem uma educação com maior significado e contextualizada.

A aplicação da aula prática nos mostrou que, quando os alunos são avaliados através de questões mais simples, diretas e objetivas, sem contextualização, ou necessidade de aplicação do conhecimento eles conseguem atingir os objetivos propostos, mas mesmo após a aplicação da aula foi possível verificar que, quando exigida uma reflexão maior, a interpretação de uma situação problema com consequente aplicação do conhecimento, os objetivos não são alcançados como gostaríamos. Isso pode indicar que tais alunos estão sendo mero receptores de informações, talvez utilizando-se da memorização, o que não gera conhecimento de fato, pois eles não conseguem aplicá-lo, nem tampouco relacioná-los. Apesar disso, foi possível perceber enorme grau de comprometimento com o desenvolvimento da atividade, eles demonstraram a capacidade de discutir a atuação dos reagentes utilizados e os resultados obtidos. Acreditamos com isso termos estimulado em tais estudantes o gosto pelo "saber fazer" através da aula experimental, como ainda seus pensamentos científicos.

Desta forma, torna-se essencial o desenvolvimento de estratégias que propiciem uma aprendizagem mais significativa, fazendo com que os alunos pensem, reflitam, resolvam problemas, proponham soluções, utilizem as terminologias próprias das ciências, sejam capazes de analisar fenômenos naturais e processos tecnológicos, ou seja, que os façam críticos o suficiente para discutir fenômenos e relacioná-los com o nosso cotidiano. Para isso novas estratégias pedagógicas se fazem necessárias. 


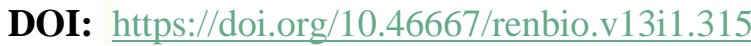

\section{Referências}

ABEGG, I.; BASTOS, F. P. Fundamentos para uma prática de ensino-investigativa em Ciências Naturais e suas tecnologias: exemplar de uma experiência em séries iniciais. Revista electronica de enseñanza de lãs ciências, v.4, n.3, p.1-15, 2005.

ANDRADE, B. S.; VASCONCELOS, C. A. O enfoque CTSA no ensino médio: um relato de experiência no ensino de biologia. Scientia Plena, v.10. n.4, p.1-9, 2014.

BRASIL. Ministério da Educação. Base Nacional Comum Curricular: Ensino médio. Brasília: MEC, 2017. Disponível em http://basenacionalcomum.mec.gov.br/. Acesso em: 26 de fevereiro de 2018.

CARMO, S.; SCHIMN, E. S. O ensino da biologia através da experimentação. Dia a dia educação, Paraná, 2008. Disponível em:

http://www.diaadiaeducacao.pr.gov.br/portals/pde/arquivos/1085-4.pdf. Acesso em: 25 de agosto de 2018.

CARVALHO, D. V. M.; SANTOS, I. R.; MENDONÇA, S. C. S; SILVA, R. P.; MATTA, L. D. M. Desenvolvimento de aulas práticas de citologia como estratégia pedagógica para auxiliar o ensino de biologia a alunos da Escola Estadual Desembargador Floriano Cavalcante - Natal/RN. In: CONGRESSO NACIONAL DE EDUCAÇÃO (CONEDU), 5. 2018, Olinda. Anais... Olinda: Editora Realize, 2018.

CHIOFI, L. C.; OLIVEIRA, M. R. F. Uso das tecnologias educacionais como ferramenta didática no processo de ensino e aprendizagem. In: JORNADA DE DIDÁTICA. DESAFIOS PARA A DOCÊNCIA E II SEMINÁRIO DE PESQUISA DO CEMAD, 3., 2014, Londrina. Anais... Londrina: Universidade Estadual de Londrina, 2014, p.329-337.

MATTA, L. D. M; MENDONÇA, S. C. S; CARVALHO, D. V. M; SANTOS, I. R. Uso do Kahoot no ensino de biologia: ferramenta de avaliação e de ensino e aprendizagem a alunos do $2^{\circ}$ ano do ensino médio. In: CONGRESSO NACIONAL DE EDUCAÇÃO (CONEDU), 5., 2018, Olinda. Anais... Olinda: Editora Realize, 2018.

MENDONÇA, S. C. S; CARVALHO, D. V. M; SANTOS, I. R. SILVA, R. P.; MATTA, L. D. M. Aplicação de aula prática laboratorial como contribuição para o ensino de biologia a alunos de uma escola estadual da cidade de Natal/RN. In: CONGRESSO NACIONAL DE EDUCAÇÃO (CONEDU), 5., 2018, Olinda. Anais... Olinda: Editora Realize, 2018.

NASCIMENTO, J. V. Citologia no ensino fundamental: dificuldades e possibilidades na produção de saberes docentes. 2016. 108f. Dissertação (Mestrado em Ensino na Educação Básica) - Centro Universitário Norte do Espírito Santo, Universidade Federal do Espírito Santo, São Mateus. 2016.

SCHER, R.; FEITOSA, V. L. C. Envoltório Nuclear, Cromatina e Cromossomo. In: SCHER, R.; FEITOSA, V. L. C. (Org.). Biologia Celular. São Cristóvão: Universidade Federal de Sergipe, CESAD, 2009. p.123-140.

SILVA, F. R.; ARANDAS, M. J. G.; MARINHO, K. S. N.; LIMA JUNIOR, N. B.; ANDRADE, M. F.; SANTOS, K. R. P. Experimentação em ciências: verificando a relação entre a teoria e a prática no ensino de genética em uma escola pública no município de Vitória do Santo Antão- PE. Revista Ciência em Extensão, v.13, n.3, p.160-170, 2017. 